\title{
Estimasi Volume Sedimentasi Waduk Sermo Menggunakan Metode RUSLE, Batimetri dan Angkutan Sedimen
}

\author{
Estimation of Sedimentation Volume Within Sermo Reservoir Using RUSLE, Bathymetry, and Sediment \\ Transport Methods
}

\author{
Annisa Wulandari ${ }^{1}$, Bambang Kun Cahyono ${ }^{2}$ \\ 1 Alumni Departemen Teknik Geodesi FT-UGM, Indonesia \\ ${ }^{2}$ Staf Pengajar Departemen Teknik Geodesi FT-UGM, Indonesia
}

Penulis Korespondensi: Bambang Kun Cahyono | Email: bambangkun@ugm.ac.id

Diterima (Received): 23/Jan/2020 Direvisi (Revised): 11/May/2020 Diterima untuk Publikasi (Accepted): 1/Jan/2020

\begin{abstract}
ABSTRAK
Waduk Sermo merupakan waduk yang dibangun Pemerintah Indonesia dengan dukungan dari Asian Development Bank dalam program Integrated Irrigation Sector Project (IISP) tahun 1996. Waduk Sermo berfungsi sebagai pengendali banjir, sumber air baku dan irigasi. Berbagai perubahan yang terjadi di daerah tangkapan air Waduk Sermo berpengaruh terhadap kondisi waduk itu sendiri. Terutama perubahan yang terjadi pada aspek limpasan air, produksi sedimen dan endapan Daerah Aliran Sungai (DAS), yang disebabkan oleh erosi di daerah tangkapan air sehingga mengakibatkan pendangkalan. Sedimentasi dalam jangka panjang menyebabkan penurunan daya tampung waduk. Untuk menanggulangi permasalahan tersebut maka perlu dilakukan estimasi volume sedimentasi untuk mengetahui keadaan terkini Waduk Sermo. Dalam kegiatan ini, dilakukan estimasi volume sedimentasi Waduk Sermo menggunakan metode RUSLE, batimetri dan angkutan sedimen. Adapun data yang digunakan dalam kegiatan ini adalah data tahun 2016, 2017 dan 2018. Pada kegiatan ini, analisis metode RUSLE pada DAS Ngrancah meliputi faktor erosivitas hujan, erodibilitas tanah, kemiringan dan panjang lereng serta tutupan dan preservasi lahan. Selain RUSLE, dilakukan analisis menggunakan metode batimetri. Metode ini menghitung sedimentasi berdasarkan data DTM dasar waduk tahun 2017 dan 2018. Dari selisih volume kedua epoch DTM, diperoleh volume dan persebaran sedimen Waduk Sermo. Selain itu dilakukan analisis metode angkutan sedimen menggunakan data kandungan tanah dalam air tahun 2016 yang diasumsikan statis sampai tahun 2018. Selama pelaksanaan analisis dengan ketiga metode RUSLE, batimetri dan angkutan sedimen perangkat lunak yang digunakan adalah ArcGIS. Hasil estimasi volume sedimentasi menggunakan metode RUSLE, batimetri dan angkutan sedimen berturut-turut sebesar 184.158,580 m3/tahun, 163.151,173 m3/ tahun dan 149.959,800 m3/tahun. Dengan demikian hasil estimasi laju ketebalan sedimen Waduk Sermo menggunakan metode RUSLE, batimetri dan angkutan sedimen sebesar 8,687 mm/tahun, 7,790 mm/tahun dan 7,074 mm/tahun. Volume dari ketiga metode diuji menggunakan uji presisi menghasilkan RSD 8,407 \% sehingga diklasifikasikan ketelitian rendah. Dari uji presisi disimpulkan bahwa metode batimetri paling presisi karena mempunyai persentase selisih sebesar $-0,766 \%$ terhadap ratarata volume sedimen.
\end{abstract}

Kata Kunci: Estimasi volume sedimentasi, daerah aliran sungai, Waduk Sermo

\begin{abstract}
Sermo Reservoir is a reservoir which was built by the Indonesian Government and supported by Asian Development Bank in program Integrated Irrigation Sector Project (IISP) in 1996. Sermo Reservoir functions as a flood control, raw water source, and irrigation. Changes that occur to the water catchment area of the Sermo Reservoir affects its condition. Especially changes that occur in aspects of water runoff, sediment production, and watershed deposition of watershed aspects which are caused by erosion in water catchment area resulting in sedimentation. Long term sedimentation causes a decrease in reservoir capacity. To overcome this problem it is necessary to estimate the sedimentation volume to determine the latest condition of the Sermo Reservoir. In this activity, volume estimation of sedimentation was conducted using RUSLE, bathymetry, and sediment transport methods. The data used in this activity are the data in 2016, 2017, and 2018. In this activity, the analysis of the RUSLE method in Ngrancah Watershed includes the factors of rainfall erosivity, soil erodibility, length and slope and land cover and preservation. In addition to RUSLE, an analysis was carried out using the bathymetry method. This method calculates sedimentation based on reservoir baseline DTM data of 2017 and 2018. From the difference between both DTM epochs, obtained sediment volume, and read of Sermo Reservoir. Besides, analysis of the sediment transport method was conducted using water soil content data of 2016 which is assumed static until 2018. While analyzing with RUSLE, bathymetry and sediment transport methods using ArcGIS Software. The results of volume estimation of sedimentation using RUSLE, sediment transport, and
\end{abstract}


bathymetry consecutively yields 184.158,580 $\mathrm{m}^{3} /$ year, 163.151,173 $\mathrm{m}^{3} /$ year, and $149.959,800 \mathrm{~m}^{3} /$ year. Thus the estimation results of sediment thickness velocity of Sermo Reservoir using RUSLE, bathymetry and sediment transport are 8,687 mm/year, 7,790 mm/year, and 7,074 mm/year. Generated volume from the methods was tested by using precision test yielding RSD 8,407 \% thus classified as low accuracy. From the precision test can be concluded that sediment transport was the most precise because it has a percentage difference of $-0,766 \%$ of the average sediment volume.

Keywords: Sedimentation volume, watershed, Sermo Reservoir, RUSLE

(C) Author(s) 2020. This is an open access article under the Creative Commons Attribution-ShareAlike 4.0 International License (CC BY-SA 4.0).

\section{Pendahuluan}

Waduk Sermo merupakan waduk yang dibangun atas kerjasama pemerintah Indonesia dengan Asian Development Bank (ADB) dalam Integrated Irrigation Sector Project (IISP) pada tahun 1994. Waduk Sermo terletak di Desa Hargowilis Kecamatan Kokap Kabupaten Kulonprogo dan menempati area seluas 157 hektar. Pada keadaan optimal, daya tampung Waduk Sermo mencapai $25.000 .000 \mathrm{~m}^{3}$ dan dimanfaatkan sebagai sumber air baku PDAM Kulonprogo, pengendalian banjir, serta aliran irigasi bagi 6954 hektar lahan pertanian di Kulonprogo (Haas, 2001).

Selama proses pembangunan sampai sekarang, Waduk Sermo mengalami berbagai perubahan termasuk volume air yang ditampung, kedalaman waduk dan volume sedimen yang mengendap di waduk. Perubahan yang terjadi pada waduk dikarenakan pola manajemen dan dinamika tata guna lahan daerah tangkapan air waduk yang berpengaruh terhadap limpasan, produksi dan sedimen Daerah Aliran Sungai (DAS) (Supangat dkk, 2014). Limpasan, produksi dan sedimen DAS merupakan faktor penting yang mempengaruhi suatu waduk. Sebab ketiga faktor tersebut berdampak langsung pada proses pengendapan material sedimen atau yang lebih dikenal sebagai proses sedimentasi. Saat sedimentasi berlangsung, tumpukan material sedimen akan menggantikan ruang yang seharusnya diisi oleh air. Jika ruang-ruang yang seharusnya terisi air digantikan oleh material sedimen dengan cepat maka daya tampung waduk akan berkurang drastis sehingga terjadi malfungsi waduk.

Menurut Hakim (2016) jika mengacu kepada Pedoman Penyusunan Teknis Rencana Rehabilitasi Lahan dan Konservasi Lahan di Daerah Aliran Sungai Kementerian Kehutanan tahun 2009, produksi sedimen DAS Ngrancah sebagai daerah tangkapan air Waduk Sermo tergolong tinggi yaitu sebesar $8 \mathrm{~mm} /$ tahun. Angka produksi sedimen merupakan refleksi kebutuhan pengerukan dan pengelolaan DAS yang lebih baik pada Waduk Sermo sebelum mengalami pendangkalan ekstrim. Untuk menanggulangi permasalahan tersebut maka perlu dilakukan estimasi volume sedimentasi sebagai tindakan awal untuk mengetahui keadaan terkini Waduk Sermo. Melalui estimasi volume sedimentasi, pengelola Waduk Sermo juga bisa memperoleh informasi tentang sumber utama material sedimen dan sebaran sedimen untuk merumuskan kebijakan terkait besaran biaya dan lama pengerukan sedimentasi.

Untuk mengestimasi volume sedimentasi terdapat beberapa metode yang dapat digunakan salah satunya yaitu Revised
Universal Soil Loss Equation (RUSLE). RUSLE dikembangkan dari persamaan USLE yang dibuat oleh Wischmeier pada tahun 1976 yang mempertimbangkan besarnya erosivitas hujan, erodibilitas tanah, kemiringan dan panjang lahan serta pengelolaan dan konservasi lahan (Hadiharyanto, 2003; Santosa dkk, 2018). Dalam kegiatan ini, metode RUSLE dibandingkan dengan metode lain, yaitu dengan metode angkutan sedimen dan metode batimetri. Metode angkutan sedimen menghitung besarnya kandungan sedimen pada air yang masuk ke waduk sedangkan metode batimetri memperhitungkan perbedaan volume antar epoch pengukuran yang diasumsikan sebagai volume sedimen. Diharapkan kegiatan ini dapat memberikan informasi mengenai volume sedimentasi Waduk Sermo menggunakan metode RUSLE, angkutan sedimen dan batimetri. Selain untuk mengetahui volume sedimentasi, kegiatan ini diharapkan memberikan perbandingan volume sedimentasi menggunakan ketiga metode RUSLE, batimetri dan angkutan sedimen sekaligus menjadi referensi pengelolaan Waduk Sermo pada masa yang akan datang.

Penelitian menggunakan metode RUSLE, batimetri dan angkutan sedimen sebelumnya pernah dilakukan oleh Hadiharyanto (2003). Penelitian tersebut mengambil studi kasus DAS Embung Banyukuwung Kabupaten Rembang. Dalam penelitian ini, digunakan data dari DAS Embung Banyukuwung untuk menentukan konstanta a dan b RUSLE. Metode RUSLE yang digunakan menghasilkan besar sedimentasi sebesar $0,91 \mathrm{~mm} /$ tahun, dibandingkan dengan metode USLE yang menghasilkan perhitungan sebesar 1,37 $\mathrm{mm} /$ tahun, metode RUSLE memiliki hasil yang lebih kecil. Penelitian mengenai sedimentasi Waduk Sermo menggunakan metode survei batimetri juga pernah dilakukan oleh Wicaksono (2014) dengan studi kasus pengukuran sedimentasi Waduk Sermo menggunakan data survei batimetri epoch 2005, 2006, 2011, 2012 dan 2013. Pengukuran batimetri menghasilkan data yang kemudian dibandingkan dengan model terain digital (MTD). Data perbedaan volume antar epoch diasumsikan sebagai volume sedimentasi. Dari penelitian ini dapat disimpulkan bahwa pengukuran menggunakan survei batimetri kurang bisa dipercaya daripada model terain digital karena ada data pengukuran yang tidak memenuhi spesifikasi IHO dan SNI dan kurangnya kerapatan jalur pengukuran di bawah standar IHO dan SNI. Kajian erosi dan sedimentasi pada DAS juga pernah dilakukan oleh Fauzi dan Maryono (2016). Obyek penelitian ini adalah DAS Kreo Hulu yang menjadi DAS prioritas utama di Indonesia. Penelitian ini menggunakan analisis Sediment Delivery Ratio 
(SDR) dan USLE. Dari analisis menggunakan metode USLE selama 2009 sampai 2014 disimpulkan bahwa DAS Kreo Hulu mengalami sedimentasi sebesar 17,45 ton; 18,78 ton; 17,83 ton; 25,70 ton; 31,62 ton; 26,17 ton. Serta analisis menggunakan faktor nilai SDR, nilai erosi serta luas DAS tahun 2009-2014 menghasilkan 2,78 ton, 2,93 ton; 2,78 ton; 4,01 ton; 4,93 ton; 4,08 ton.

\section{Data dan Metodologi}

\subsection{Data dan Lokasi}

Kegiatan ini dilaksanakan di lokasi Waduk Sermo pada DAS Ngrancah yang meliputi Desa Hargowilis dan Hargotirto Kecamatan Kokap Kabupaten Kulonprogo. Pengambilan data ketiga metode dilakukan di sungai yang masuk ke waduk serta di Waduk Sermo. Data yang dihasilkan dari proses akuisisi secara langsung menjadi data primer, yaitu data DTM dasar Waduk Sermo tahun 2017 dan 2018 serta data kandungan tanah dalam air tahun 2016 yang diasumsikan statis sampai tahun 2018. Data lain yang digunakan dalam kegiatan ini adalah data sekunder antara lain data curah hujan DAS Ngrancah dari Satelit Tropical Rainfall Measuring Mission (TRMM) lembaga Japan Aerospace Exploration Agency (JAXA) tahun 2018, DEMNAS liputan Bagelen tahun 2018 dari Badan Informasi Geospasial (BIG) dan citra satelit Sentinel 2B liputan Kecamatan Kokap tahun 2018 dari European Space Agency (ESA). Data-data tersebut kemudian diolah menggunakan pendekatan teknologi geoinformasi dengan perangkat lunak ArcGIS 10.3.

\subsection{Penentuan Volume Sedimentasi dengan Metode RUSLE}

Metode RUSLE mempunyai beberapa faktor penyusun yang dapat dikalkulasikan pada persamaan 1 (Prasannakumar, 2012).

$$
A=\operatorname{RiKLSCP}
$$

Keterangan:

$A$ :Volume tanah yang hilang setiap tahun (ton/ha/tahun)

$R i$ : Faktor erosivitas hujan (kJ/tahun)

$K$ : Faktor erodibilitas tanah (kJ/tahun)

$L S$ : Faktor kemiringan dan panjang lereng

$C P$ : Faktor tutupan dan preservasi lahan

Dari keenam faktor penyusun yang sudah disederhanakan menjadi empat faktor, perlu diketahui nilai masing-masing faktor tersebut melalui perhitungan secara terpisah

\subsubsection{Delineasi Daerah Aliran Sungai (DAS)}

Delineasi DAS adalah pemberian batas DAS, dengan menggunakan aplikasi ArcMap 10.3, delineasi dimulai dengan pembuatan raster depressionless DEM dengan tool sink. Setelah diproses dengan tool sink kemudian diperoleh raster untuk selanjutnya dianalisis arah aliran di daerah tersebut menggunakan tool flow direction. Selanjutnya akumulasi aliran diperoleh menggunakan tool flow accumulation. Langkah selanjutnya adalah menentukan titik tuang (pour point) dari DEM dengan mendigitasi pour point pada sungai orde 3 yang masuk ke Waduk Sermo. Setelah itu, pour point yang didapat dianalisis dengan flow direction untuk menghasilkan area DAS.

\subsubsection{Penentuan Faktor Erosivitas Hujan}

Faktor erosivitas hujan dihitung dengan persamaan 2 (Prasannakumar, 2012).

$$
R i=\Sigma_{i}^{12} 1,735 \times 10^{\left(1,5 \log _{10}\left(\frac{P i^{2}}{P}\right)-0,08188\right)}
$$

Keterangan:

$R i$ : Indeks erosivitas hujan

$\mathrm{Pi}$ : Jumlah curah hujan bulanan (mm)

$P$ : Jumlah curah hujan tahunan (mm)

Persamaan 2 dikalkulasi menggunakan data curah hujan harian DAS Ngrancah dari satelit TRMM JAXA tahun 2018. Area DAS Ngrancah sendiri masuk ke dalam empat cakupan area stasiun curah hujan dari satelit TRMM. Keempat stasiun tersebut memiliki koordinat lokasi:
a. $7,75^{\circ} \mathrm{LS} 110,05^{\circ} \mathrm{BT}$
b. $7,75^{\circ} \mathrm{LS} 110,15^{\circ} \mathrm{BT}$
c. $7,85^{\circ} \mathrm{LS} 110,05^{\circ} \mathrm{BT}$
d. $7,85^{\circ}$ LS $110,15^{\circ} \mathrm{BT}$

Data yang diperoleh merupakan hasil penyortiran dan perhitungan data curah hujan per jam berdasarkan persentase luas area DAS tiap-tiap grid yang terbentuk oleh koordinat terhadap luas total DAS. Pembagian DAS seperti pada Gambar 2.1.

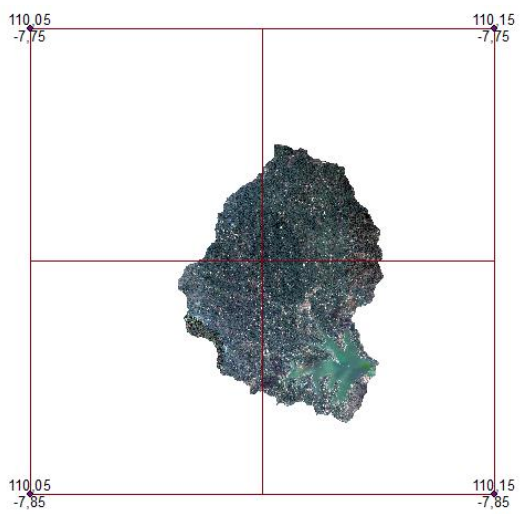

Gambar 2.1 Grid area DAS Ngrancah terhadap Stasiun Curah Hujan

\subsubsection{Penilaian Faktor Erodibilitas Tanah}

Perhitungan nilai erodibilitas tanah atau nilai ketahanan tanah terhadap erosi diawali dengan membuat peta jenis tanah DAS Ngrancah. Peta jenis tanah diproduksi dari clipping area DAS Ngrancah dengan peta jenis tanah Kabupaten Kulonprogo seperti pada Gambar 2.2 . 


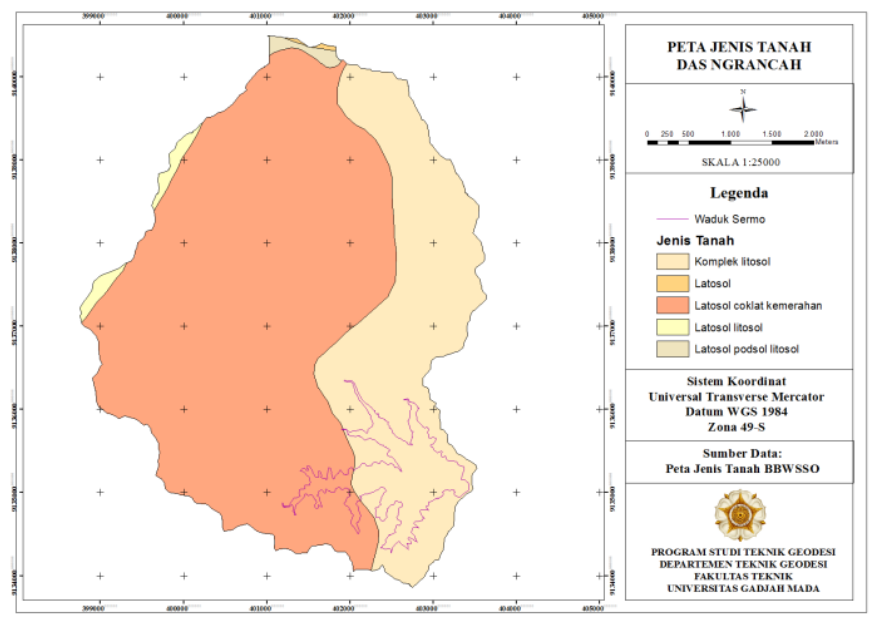

Gambar 2.2 Peta jenis tanah DAS Ngrancah

Hasil clip peta menunjukkan jenis tanah yang ada di DAS Ngrancah. Jenis tanah DAS Ngrancah yang dihasilkan dari clip memiliki nilai erodibilitas yang berbeda-beda. Nilai erodibilitas ini kemudian dikalikan dengan persentase luas jenis tanah pada DAS Ngrancah. Akumulasi perkalian tersebut merupakan faktor erodibilitas tanah dalam satuan kilojoule.

\subsubsection{Penilaian Faktor Kemiringan Lereng}

Analisis kemiringan lereng DAS Ngrancah dimulai dari analisis slope pada DEMNAS, kemudian DEM tersebut diklasifikasikan menurut kelas-kelas kelerengan. Faktor kemiringan dan panjang lereng dibuat dengan melakukan analisis slope pada DEM hasil operasi clip antara DEMNAS dengan DAS Ngrancah. Kelas-kelas kemiringan slope dibuat ke dalam satuan persen dengan kelas kemiringan mulai dari $0-8 \%, 8-15 \%, 15-25 \%, 25-40 \%$ dan $>40 \%$ (Kementerian Kehutanan, 2009). Setiap kelas kemiringan lereng mempunyai nilai yang berbeda-beda, sehingga tidak dapat dikalikan dengan luas total DAS secara langsung. Oleh karena itu, perlu diketahui luasan setiap kelas kemiringan. Setelah diketahui luasan setiap kelas, nilai luasan dikalikan dengan nilai kemiringan sehingga diperoleh nilai faktor kemiringan dan panjang lereng.

\subsubsection{Penilaian Faktor Tutupan-Preservasi Lahan}

Pembuatan faktor tutupan dan preservasi lahan menggunakan citra satelit Sentinel 2B liputan Kecamatan Kokap. Citra satelit yang masih dalam bentuk raw dikoreksi dengan koreksi radiometrik berupa nilai DN (Digital Number) dan koreksi reflektansi untuk menghilangkan kesalahan akibat pengaruh atmosfer. Setelah dikoreksi, citra satelit siap untuk dianalisis pada software ArcMap menggunakan metode supervised classification yang memerlukan area of interest (AOI) sebagai sampel klasifikasi area. Pengambilan sampel melalui AOI sebisa mungkin ditempatkan pada area yang benar-benar mewakili suatu kelas. Diperlukan sampel lebih pada setiap kelas yang diklasifikasikan melalui AOI untuk menambah kepresisian hasil. kepresisiannya dengan uji lapangan. Uji lapangan ini dilakukan dengan mencocokkan hasil klasifikasi di peta dengan keadaan sebenarnya di lapangan.

\subsection{Penentuan Volume Sedimentasi Metode Batimetri}

DTM Waduk Sermo yang digunakan merupakan data pengukuran yang dilakukan sebanyak dua kali pada tahun 2017 dan 2018. DTM yang digunakan memiliki referensi D WGS 1984 dengan proyeksi transverse mercator dan zona 49S. DTM diperoleh melalui pengukuran menggunakan echosounder dan khusus tahun 2018 digabung dengan data dari Unmanned Aerial Vehicle (UAV). Data koordinat yang dihasilkan dari proses akuisisi metode batimetri dikoreksikan dengan nilai barcheck dan draft transducer dan nilai kedangkalan sebesar 1 meter.

Dari kedua DTM tahun 2017 dan 2018 dilakukan kalkulasi surface volume untuk mengetahui besaran volume masing-masing. Untuk memperoleh visualisasi sebaran sedimentasi, dilakukan analisis cut and fill pada Digital Terrain Model di ArcMap seperti pada Gambar 2.3.

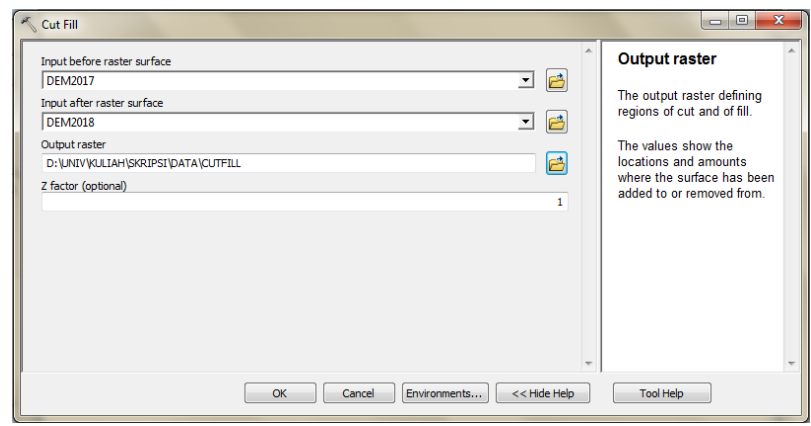

Gambar 2.3 Tangkapan layar proses cut and fill

Referensi yang digunakan dalam proses cut fill sama dengan DTM asal yakni D WGS 1984 dengan UTM 49S. Before raster surface merupakan raster yang menunjukkan keadaan waduk semula tahun 2017. After raster surface merupakan raster yang menunjukkan keadaan waduk tahun 2018. Output raster menunjukkan direktori penyimpanan hasil analisis cut and fill.

Volume sedimen Waduk Sermo diperoleh melalui pengurangan atau selisih antara surface volume DTM dasar waduk tahun 2017 dan 2018. Hasil perhitungan sedimen dari selisih surface volume, masih berupa ton/tahun sehingga perlu dikonversi ke dalam meter kubik/tahun dengan membagi terhadap massa jenis sedimen. Laju ketebalan sedimen dalam satuan milimeter/tahun diperoleh melalui pembagian volume sedimen yang bersatuan meter kubik/tahun dengan luas area (meter persegi).

2.4. Penentuan Volume Sedimentasi dengan Metode Angkutan Sedimen 
Kandungan sedimen pada waduk dihitung memakai metode angkutan sedimen. Angkutan sedimen mempertimbangkan debit waduk dan volume material sedimen yang terkandung dalam air yang masuk ke waduk. Sedimen yang terkandung dalam air diukur pada empat titik berbeda. Keempat titik pengukuran sedimen terdapat di aliran Sungai Gelo, Sungai Lurung, Sungai Ngrancah dan Sungai Bengkok. Hasil sampel sedimen dari keempat titik lalu dikalikan dengan debit masing-masing sungai sesuai dengan persamaan 3 dan 4 (Kironoto, 2003).

$$
S D R=0,5656 \times A^{-0,11}
$$

Keterangan:

SDR : Nisbah penghantaran sedimen

$A \quad$ : Luas DAS $\left(\mathrm{km}^{2}\right)$

$$
S y=\operatorname{Ea} \times S D R
$$

Keterangan:

$$
\begin{array}{ll}
\text { Sy } & \text { : Hasil sedimen (ton/ha/tahun) } \\
\text { Ea } & : \text { Nilai erosi (ton/ha/tahun) } \\
\text { SDR } & : \text { Nisbah penghantaran sedimen }
\end{array}
$$

Hasil estimasi volume dengan persamaan 4. masih dalam satuan ton/hari, untuk itu maka perlu dikonversi ke dalam meter kubik/tahun dengan membagi hasil kalkulasi persamaan dengan massa jenis sedimen. Setelah itu, untuk mengetahui laju ketebalan sedimen maka dikonversi kembali ke dalam milimeter/tahun dengan membagi hasil konversi meter kubik/tahun dengan luas area dalam satuan meter persegi/tahun.

\subsection{Uji presisi}

Dalam mengestimasi volume sedimentasi, kegiatan ini menggunakan tiga metode yaitu metode RUSLE, batimetri dan angkutan sedimen. Dari ketiga metode yang digunakan, perlu diketahui tingkat kepresisian masingmasing metode. Untuk itu, maka dilakukan uji presisi terhadap hasil setiap metode yang sudah disamakan satuannya ke dalam meter kubik/tahun. Perhitungan uji presisi dilaksanakan menggunakan persamaan 5 dan 6 (Sumardi, 2005).

$$
S D=\sqrt{\frac{\Sigma\left(X_{i}-\bar{X}\right)^{2}}{n}}
$$

Keterangan:

$S D:$ Standar deviasi

$X i$ : Data ke i

$\bar{X}$ : Rerata data

$$
R S D=\frac{S D}{\bar{X}} \times 100 \%
$$

$R S D$ : Relative standard deviation

$S D$ : Standar deviasi

$\bar{X} \quad$ : Rerata data

Nilai RSD yang diperoleh kemudian dinilai tingkatan kepresisiannya menggunakan Tabel 2.1.
Tabel 2.1 Klasifikasi kepresisian RSD (Sumardi, 2005)

\begin{tabular}{cc}
\hline Nilai RSD (\%) & Tingkatan \\
\hline RSD $\leq 1$ & Sangat teliti \\
$1<$ RSD $\leq 2$ & Teliti \\
$2<$ RSD $\leq 5$ & Ketelitian sedang \\
RSD $>5$ & Ketelitian rendah \\
\hline
\end{tabular}

\section{Hasil dan Pembahasan}

3.1. Perhitungan Volume Sedimentasi Menggunakan Metode RUSLE

Dalam metode RUSLE, perhitungan volume sedimentasi memerlukan area DAS sebagai dasar penilaian setiap faktor. DEM yang digunakan dalam delineasi DAS ini diperoleh dari DEMNAS liputan Bagelen yang memiliki resolusi spasial sebesar 0,27 arcsecond. Oleh karena itu, dilakukan proses delineasi DAS yang dimulai dari pembuatan raster depressionless DEM (DEM tanpa cekungan) melalui tool sink sampai dengan menggunakan tool watershed, tool watershed memerlukan data DEM flow direction dan pour point, pada software ArcGIS. Proses delineasi DAS menghasilkan lima area sub DAS di DAS Ngrancah, seperti pada Gambar 3.1.

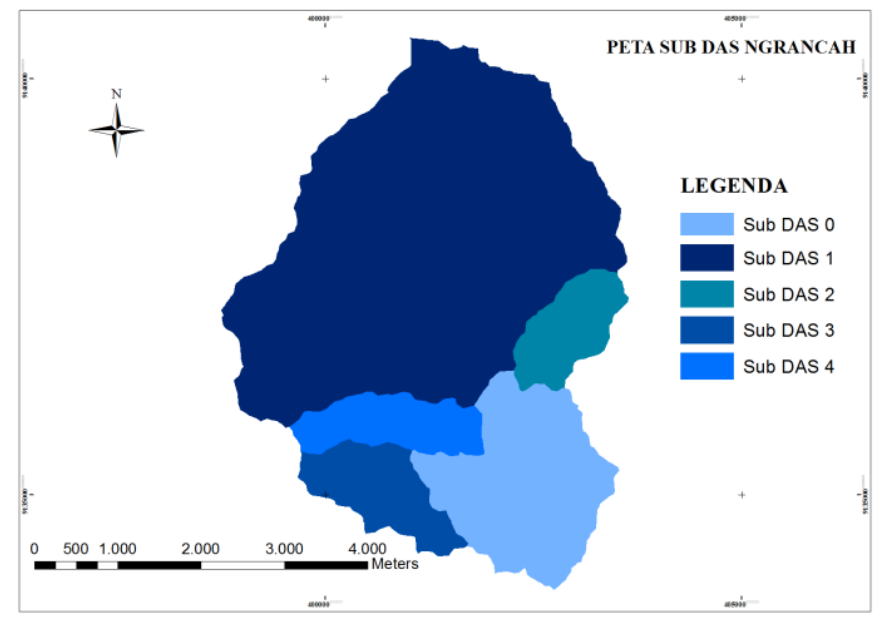

Gambar 3.1 Peta sub DAS Ngrancah

Area sub DAS terbesar adalah sub DAS 1 dengan luas 1361,520 Ha dan yang terkecil adalah sub DAS 2 dengan luas 118,470 Ha. Total luas keseluruhan dari DAS Ngrancah adalah sebesar 2120,033 Ha. Meliputi 3 Desa di Kecamatan Kokap, yaitu Desa Hargotirto, Desa Hargowilis dan Desa Kalirejo.

Setelah proses delineasi DAS, kemudian dilakukan penilaian terhadap masing-masing faktor RUSLE di DAS Ngrancah. Antara lain faktor erosivitas hujan, faktor erodibilitas tanah, faktor kemiringan lahan dan faktor tutupan-preservasi lahan.

Hasil penilaian faktor erosivitas hujan seperti pada Gambar 3.2. Erosivitas hujan terbesar terjadi pada bulan Januari sebesar 278,057 kJ/tahun. Hal tersebut sebanding dengan besarnya curah hujan yang terjadi pada bulan 
Januari seperti pada Gambar 3.3, sementara itu curah hujan paling kecil terjadi pada bulan Agustus sehingga memiliki nilai erosivitas paling kecil yaitu $0 \mathrm{~kJ} /$ tahun. Apabila ditotalkan seluruh nilai erosivitas hujan sepanjang tahun 2018, menghasilkan angka sebesar 620,147 $\mathrm{kJ} /$ tahun.

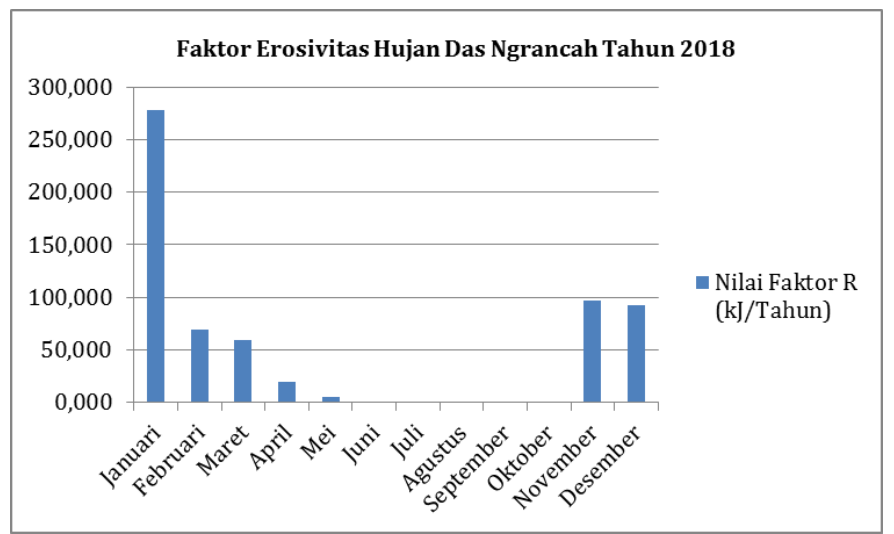

Gambar 3.2 Nilai faktor erosivitas hujan DAS Ngrancah

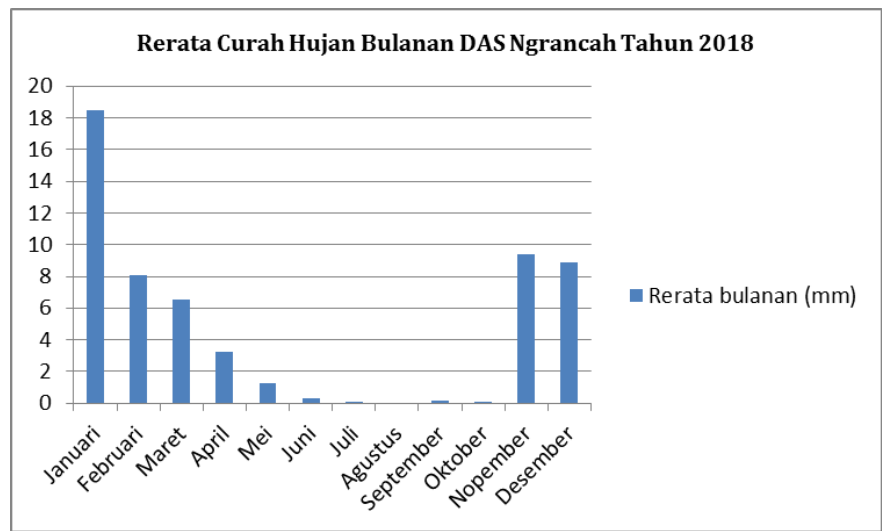

Gambar 3.3 Nilai curah hujan bulanan DAS Ngrancah

Faktor erodibilitas tanah (K) yang diperoleh di DAS Ngrancah menghasilkan luas dan nilai per jenis tanah. Nilai erodibilitas tanah DAS Ngrancah seperti pada Tabel 3.1, hasil tersebut menunjukkan bahwa terdapat dua kelompok tanah yaitu tanah latosol dan litosol.

Tabel 3.1 Nilai erodibilitas tanah DAS Ngrancah

\begin{tabular}{llc}
\multicolumn{3}{c}{ (Ashari, 2013) } \\
\hline \multicolumn{1}{c}{ Jenis tanah } & \multicolumn{1}{c}{ Luas } & \multicolumn{1}{c}{ K } \\
\hline Komplek Litosol & 649,911 & 0,29 \\
Latosol coklat kemerahan & $1.470,187$ & 0,31 \\
Latosol podsol litosol & 11,880 & 0,31 \\
Latosol & 1,954 & 0,31 \\
Latosol litosol & 22,682 & 0,31 \\
\hline
\end{tabular}

Hasil penilaian menunjukkan DAS Ngrancah didominasi oleh jenis tanah latosol coklat kemerahan dengan nilai erodibilitas sebesar 0,31. Latosol merupakan jenis tanah yang relatif resisten terhadap erosi sebab mempunyai agregat tanah yang kuat. Selain resisten terhadap erosi, latosol juga merupakan jenis tanah yang gembur. Jenis tanah yang lain adalah litosol, jenis tanah ini mempunyai nilai erodibilitas yang lebih kecil dibandingkan latosol sehingga dapat disimpulkan bahwa litosol relatif lebih resisten terhadap erosi (Ashari, 2013). Peta erodibilitas tanah DAS Ngrancah ditunjukkan oleh Gambar 3.4.

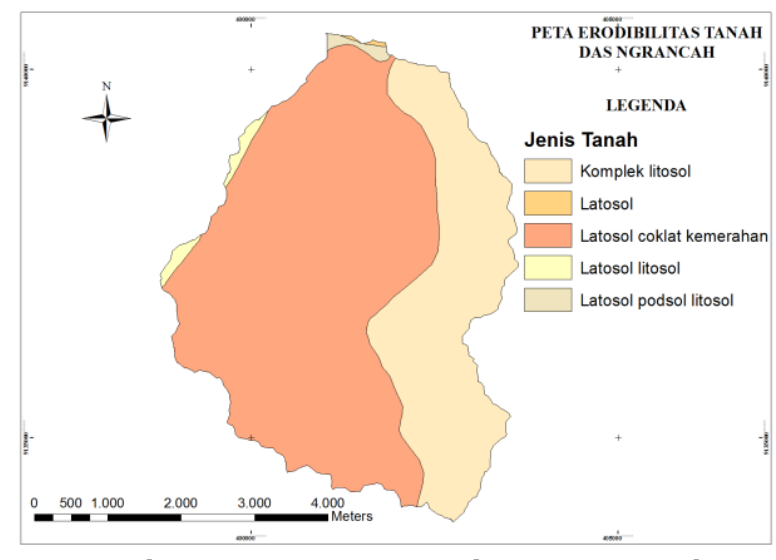

Gambar 3.4 Peta jenis tanah DAS Ngrancah

Faktor kemiringan lereng (LS) merupakan faktor RUSLE yang dihitung berdasarkan kelas-kelas kemiringan lereng DAS Ngrancah. Klasifikasi kemiringan lahan di DAS Ngrancah seperti pada Tabel 3.2.

Tabel 3.2 Kelas kemiringan lahan DAS Ngrancah

\begin{tabular}{llll}
\hline Kelas & Persentase (\%) & Luas (Ha) & Nilai LS \\
\hline 1 & $0-8$ & 175,204 & 0,4 \\
2 & $8-15$ & 228,857 & 1,4 \\
3 & $15-25$ & 594,808 & 3,1 \\
4 & $25-40$ & 831,697 & 6,8 \\
5 & $>40$ & 289,487 & 9,5 \\
\hline
\end{tabular}

Kemiringan lereng yang dihasilkan pada Tabel 3.2. menunjukkan bahwa DAS Ngranah didominasi oleh lahan berkemiringan $25-40 \%$. Nilai LS pada kelas kemiringan 4 sebesar 6,8. Visualisasi luasan dan kelas kemiringan ditunjukkan oleh Gambar 3.5.

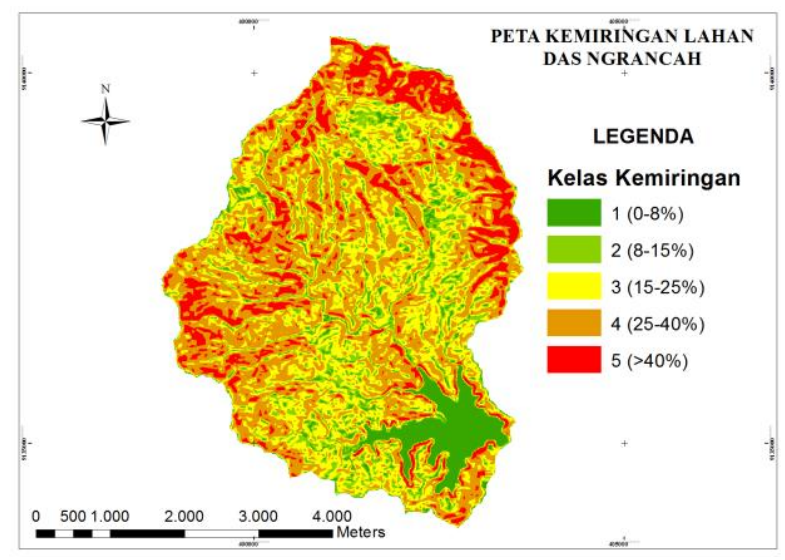

Gambar 3.5 Peta kemiringan lahan DAS Ngrancah 
Faktor tutupan-preservasi lahan (CP) DAS Ngrancah menghasilkan klasifikasi penggunaan lahan seperti pada Tabel 3.3.

Tabel 3.3 Nilai faktor tutupan-preservasi lahan DAS Ngrancah

\begin{tabular}{lrr}
\hline \multicolumn{1}{c}{ Nama kelas } & \multicolumn{1}{c}{ Luas (Ha) } & \multicolumn{1}{c}{ Nilai CP } \\
\hline Pemukiman & 115,476 & 0 \\
Waduk & 83,351 & 0 \\
Tegalan & 818,057 & 0,28 \\
Kebun campuran & 824,000 & 0,2 \\
Semak belukar & 278,901 & 0,3 \\
\hline
\end{tabular}

Kelas penggunaan lahan dibagi menjadi lima kelas yaitu pemukiman, waduk, tegalan, kebun campuran dan semak belukar. Mayoritas jenis penggunaan lahan di DAS Ngrancah adalah kebun campuran seluas 824,000 Ha dan yang paling kecil luasannya adalah waduk seluas 83,351 Ha. Visualisasi jenis penggunaan lahan seperti pada Gambar 3.6.

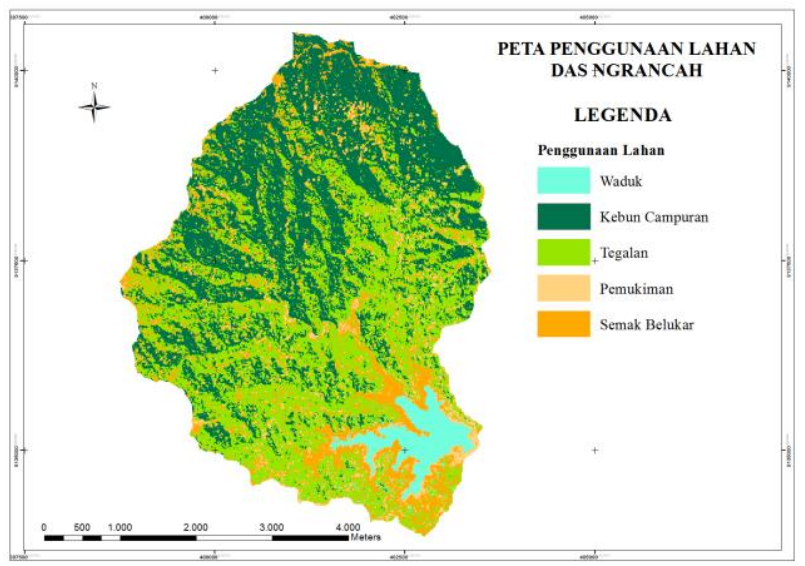

Gambar 3.6 Peta penggunaan lahan DAS Ngrancah

Secara keseluruhan, hasil perhitungan volume sedimentasi menggunakan metode RUSLE seperti pada Tabel 3.4. Jumlah volume sedimentasi dihitung dengan cara mengalikan Ea dengan Sediment Delivery Ratio (SDR) sehingga menghasilkan angka sebesar 189.683,337 ton/tahun. Jika dikalikan dengan berat jenis suspensi sebesar 1,03 maka akan menghasilkan angka sebesar $184.158,580 \mathrm{~m}^{3} /$ tahun atau setebal $8,687 \mathrm{~mm} /$ tahun.

Tabel 3.4 Hasil perhitungan RUSLE DAS Ngrancah

\begin{tabular}{lccc}
\hline $\begin{array}{c}\text { Tata Guna } \\
\text { Lahan }\end{array}$ & $\begin{array}{c}\text { Jumlah Ea } \\
\text { (ton/ha/t } \\
\text { hn) }\end{array}$ & $\begin{array}{c}\text { Jumlah } \\
\text { Luas (Ha) }\end{array}$ & $\begin{array}{c}\text { Jumlah Ea x } \\
\text { Luas } \\
\text { (ton/Ha) }\end{array}$ \\
\hline $\begin{array}{l}\text { Semak } \\
\text { Belukar }\end{array}$ & $2.366,482$ & 283,588 & $73.358,564$ \\
$\begin{array}{l}\text { Kebun } \\
\text { Campuran }\end{array}$ & $1.577,655$ & 821,062 & $179.649,336$ \\
Tegalan & $2.208,717$ & 817,175 & $216.256,351$ \\
\hline
\end{tabular}

\begin{tabular}{lrrr} 
Pemukiman & 0,000 & 114,877 & 0,000 \\
Waduk & 0,000 & 83,331 & 0,000 \\
Jumlah & $6.152,853$ & $2.120,033$ & $469.264,251$ \\
\hline
\end{tabular}

Perhitungan volume sedimentasi lebih detail tersaji pada Tabel 3.5. Perhitungan luas setiap sub DAS ditampilkan lengkap dengan sedimen ( $E a$ ) yang dihasilkan. Tabel 3.5. menunjukkan bahwa sub DAS 1 menempati area yang paling luas akan tetapi tidak menjadi area yang memproduksi sedimen terbesar. Volume sedimentasi yang paling masif dihasilkan oleh sub DAS 4, sebesar 115,910 $\mathrm{m}^{3} / \mathrm{Ha}$.

Tabel 3.5 Volume sedimentasi sub DAS Ngrancah

\begin{tabular}{crrr}
\hline Bagian & $\begin{array}{c}\text { Jumlah } \mathbf{E a} \\
\left(\mathbf{m}^{3} / \mathbf{H a}\right)\end{array}$ & \multicolumn{1}{c}{$\begin{array}{c}\text { Jumlah } \\
\text { Luas }\end{array}$} & $\begin{array}{l}\text { Jumlah } \boldsymbol{E a} \mathbf{x} \\
\text { Luas } \\
\left(\mathbf{m}^{3} / \mathbf{t a h u n}\right)\end{array}$ \\
\hline Sub DAS 0 & 56,040 & 365,580 & $20.487,084$ \\
Sub DAS 1 & 101,497 & $1.361,520$ & $138.189,828$ \\
Sub DAS 2 & 86,079 & 118,470 & $10.197,767$ \\
Sub DAS 3 & 101,673 & 142,800 & $14.518,902$ \\
Sub DAS 4 & 115,910 & 131,700 & $15.265,294$ \\
\hline
\end{tabular}

3.2. Perhitungan Volume Sedimentasi Menggunakan Metode Batimetri

Perhitungan volume sedimentasi dilakukan dengan menyelisihkan volume tampungan waduk epoch 2017 dan 2018. Volume tampungan tersebut dihitung dengan DTM dasar Waduk Sermo hasil pengukuran batimetri seperti yang terlihat pada Gambar 3.7 dan Gambar 3.8. Selisih volume antar tahun tersebut kemudian diasumsikan sebagai volume sedimentasi yang mengendap selama satu tahun di Waduk Sermo.

Perhitungan volume sedimentasi menggunakan metode batimetri menghasilkan volume sebesar 170.100,215 ton/tahun (Tabel 3.6) atau jika dikonversi ke dalam satuan $\mathrm{m}^{3}$ sebesar $165.145,840 \mathrm{~m}^{3}$ /tahun. Konversi dilakukan dengan membagi volume sedimentasi dengan berat jenis suspensi. Laju ketebalan sedimen diketahui sebesar 7,790 $\mathrm{mm} /$ tahun dengan cara membagi volume dalam satuan meter kubik dengan luas dalam meter persegi. Kemudian dikonversi dari satuan meter ke dalam milimeter dengan dikalikan 1000.

Tabel 3.6 Selisih volume sedimentasi tahun 2017 dan 2018

\begin{tabular}{cr}
\hline Tahun & \multicolumn{1}{c}{ Volume (ton) } \\
\hline 2017 & $21.066 .415,285$ \\
2018 & $20.896 .315,070$ \\
Selisih & $170.100,215$ \\
\hline
\end{tabular}




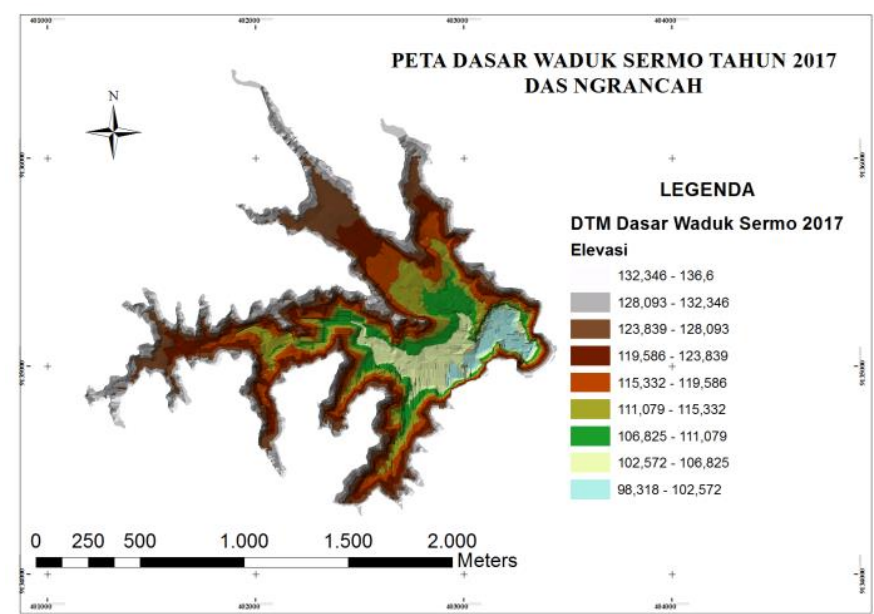

Gambar 3.7 DTM dasar Waduk Sermo tahun 2017

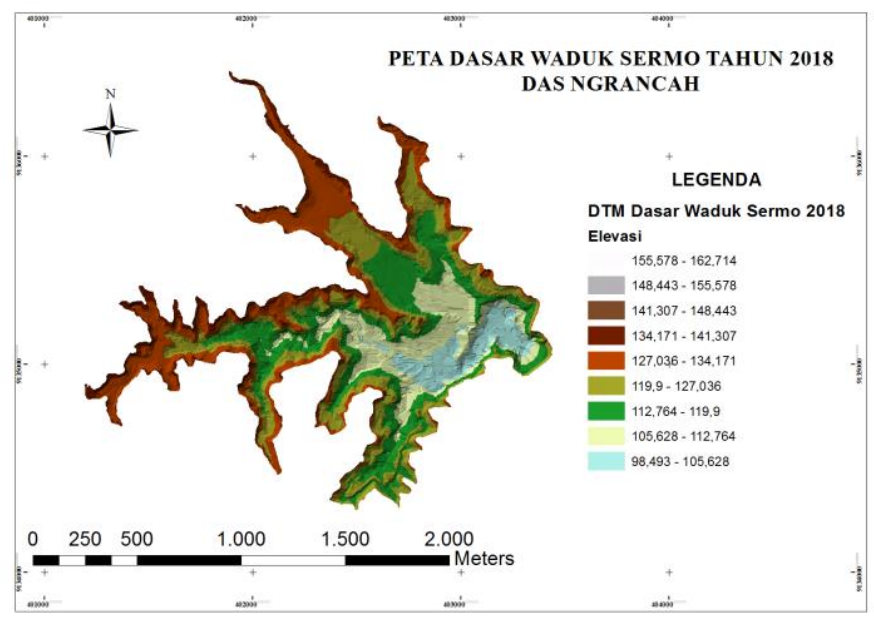

Gambar 3.8 DTM dasar Waduk Sermo tahun 2018

Selain diperoleh nilai sedimentasi, dengan menggunakan DTM dasar waduk, juga dapat diperoleh sebaran sedimentasi dan besar volume sedimentasinya, yang ditunjukkan oleh Gambar 3.9. Pada Gambar 3.9 terlihat gradasi warna merah ke oranye dan hijau ke kuning yang menggambarkan sebaran sedimen. Warna merah sampai oranye menunjukkan area yang mengalami kenaikan sedimen dibanding tahun sebelumnya, sedangkan warna hijau sampai kuning menunjukkan area yang mengalami penurunan sedimen dibandingkan tahun sebelumnya. Warna merah pada Gambar 3.9 menunjukkan area yang paling banyak mengalami penambahan material sedimen, sementara area berwarna hijau menunjukkan area yang paling banyak mengalami penurunan sedimen di dasar waduk dibandingkan tahun sebelumnya.

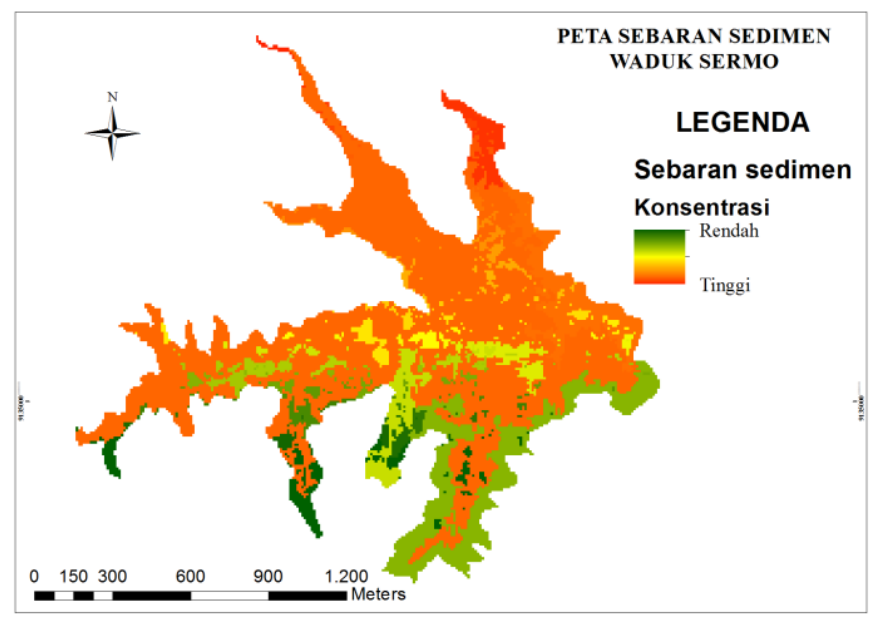

Gambar 3.9 Sebaran sedimen Waduk Sermo

3.3. Perhitungan Volume Sedimentasi Menggunakan Metode Transpor Sedimen

Tabel 3.7 Perhitungan volume sedimentasi metode angkutan sedimen DAS Ngrancah

\begin{tabular}{lrrr}
\hline \multicolumn{1}{c}{ Bulan } & Qs Inflow & \multicolumn{1}{c}{ Qs Outflow } & Selisih (ton) \\
\hline Januari & $2.705,777$ & 312,301 & $2.393,476$ \\
Februari & $1.720,340$ & 201,425 & $1.518,915$ \\
Maret & $1.310,656$ & 72,148 & $1.238,508$ \\
April & 382,770 & 202,082 & 180,684 \\
Mei & 157,987 & 285,339 & 127,352 \\
Juni & 169,245 & 281,026 & 111,781 \\
Juli & 11,681 & 33,936 & 22,256 \\
Agustus & 10,511 & 7,808 & 2,704 \\
September & 4,505 & 7,556 & 3,051 \\
Oktober & 4,505 & 7,808 & 3,303 \\
November & 942,282 & 16,192 & 926,090 \\
Desember & $1.231,757$ & 26,321 & $1.205,436$ \\
\hline \multicolumn{5}{c}{ Jumlah } & & $7.198,070$ \\
\hline
\end{tabular}

Metode ketiga yang digunakan dalam penelitian ini adalah metode angkutan sedimen, yang menghitung kandungan tanah yang terkandung dalam air yang masuk dan keluar waduk. Pengambilan sampel air dilakukan di sejumlah titik, yaitu di Sungai Ngrancah Menguri, Ngrancah Plaosan, Ngrancah Bendung, Gelo, Kedung Cawilan/Lurung dan Sungai Bengkok. Hasil dari metode angkutan sedimen seperti pada Tabel 3.7, sebesar 7198,070 ton. Angka tersebut kemudian dibagi berat jenis sedimen padatan sebesar 0,048 sehingga menghasilkan $149.959,8001 \mathrm{~m}^{3} /$ tahun atau setara sedimen setebal 7,074 $\mathrm{mm} /$ tahun. 
Volume sedimentasi Waduk Sermo yang dihitung menggunakan metode angkutan sedimen, merupakan nilai yang paling kecil dibandingkan tahun-tahun sebelumnya, merujuk pada Gambar 3.10 .

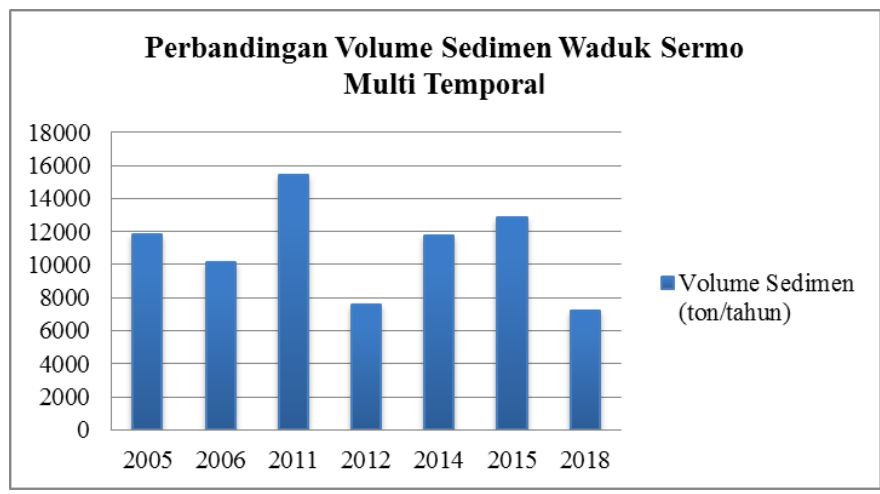

Gambar 3.10 Perbandingan volume sedimen Waduk Sermo multi temporal

3.4. 3.4. Evaluasi Perhitungan Volume Sedimentasi Menggunakan Metode RUSLE, Batimetri dan Angkutan Sedimen

Evaluasi perhitungan volume sedimentasi metode RUSLE, survei batimetri dan angkutan sedimen seperti pada Gambar 3.11. Volume sedimen dari yang paling kecil ke paling besar dihasilkan oleh metode angkutan sedimen, batimetri kemudian yang paling tinggi dengan metode RUSLE. Dari hasil ketiga metode, didapatkan perbandingan metode RUSLE, batimetri dan angkutan sedimen secara berturut-turut sebesar 0,81:0,9:1 atau setara dengan laju ketebalan 8,687:7,790:7,074 mm/tahun.

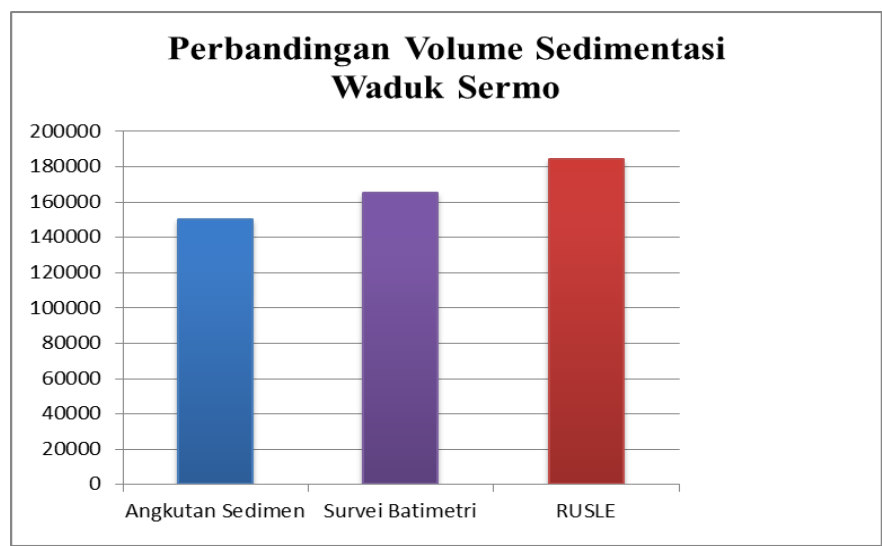

Gambar 3.11 Perbandingan volume sedimentasi Waduk Sermo

Evaluasi metode estimasi volume sedimentasi secara numeris dapat menggunakan uji presisi. Apabila ketiga metode RUSLE, angkutan sedimen dan batimetri dievaluasi menggunakan uji presisi dengan Persamaan 5 dan 6 maka akan menghasilkan nilai pada Tabel 3.8.

Parameter yang dibutuhkan untuk menguji kepresisian metode RUSLE, angkutan sedimen dan batimetri adalah nilai rata-rata dan simpangan baku. Pada Tabel 3.8 nilai rata-rata volume yaitu $166.421,407$ ton dengan simpangan baku 17.135,035 ton. Relative Standard Deviation (RSD) yang dihasilkan dari perhitungan adalah $8,407 \%$. Nilai RSD diklasifikasikan ke dalam tingkatan ketelitian rendah.

Tabel 3.8 Parameter uji presisi

\begin{tabular}{lr}
\hline Parameter & \multicolumn{1}{c}{ Nilai } \\
\hline Rerata & $166.421,407 \mathrm{~m}^{3}$ \\
SD & $17.135,035 \mathrm{~m}^{3}$ \\
RSD & $8,407 \%$ \\
\hline
\end{tabular}

Metode yang memiliki selisih nilai terbesar terhadap rata-rata volume ketiga metode adalah metode RUSLE sebanyak 10,658 \%. Metode angkutan sedimen menghasilkan selisih sebesar $-9,892 \%$. Metode angkutan sedimen memiliki selisih sebesar $-9,892 \%$ terhadap nilai rata-rata dari ketiga metode yang digunakan sehingga batimetri menjadi metode dengan persentase selisih paling kecil. Karena persentase selisih metode batimetri terhadap rata-rata hasil volume menunjukkan hasil paling kecil, dapat disimpulkan bahwa metode batimetri adalah metode yang paling presisi seperti pada Tabel 3.9.

Tabel 3.9 Persentase selisih hasil setiap metode terhadap rata-rata volume sedimen ketiga metode

\begin{tabular}{cr}
\hline Metode & Persentase selisih \\
\hline Angkutan Sedimen & $-9,892 \%$ \\
Batimetri & $-0,766 \%$ \\
RUSLE & $10,658 \%$ \\
\hline
\end{tabular}

Persentase selisih pada Tabel 3.9. menunjukkan bahwa terdapat selisih yang besar di antara ketiga metode. Metode yang menunjukkan selisih terbanyak merupakan metode RUSLE kemudian diikuti oleh metode angkutan sedimen. Hal tersebut terjadi karena terdapat perbedaan signifikan pada faktor debit Waduk Sermo, yang menjadi salah satu parameter dalam persamaan 3 dan 4 . Tahun 2018 DAS Ngrancah mengalami curah hujan yang kecil seperti pada Gambar 3.3, sehingga debit yang dihasilkan oleh sungai yang masuk ke Waduk Sermo menurun dibandingkan dengan tahun-tahun sebelumnya. Faktor debit yang bernilai kecil berdampak pada menurunnya kandungan tanah dalam air yang masuk ke Waduk Sermo. Sebab debit air berbanding lurus dengan kandungan sedimen dalam air. Grafik rata-rata debit Waduk Sermo ditunjukkan oleh Gambar 3.12.

Selain faktor debit air yang menurun dibandingkan tahun-tahun sebelumnya, terdapat faktor lain yang dapat menyebabkan jangkauan yang besar terhadap hasil perhitungan volume. Pada persamaan RUSLE, faktor erodibilitas tanah dihitung menggunakan peta jenis tanah Kabupaten Kulonprogo yang berskala kecil dan belum diperbaharui. Di samping faktor erodibilitas, pada uji faktor tutupan dan preservasi lahan, matriks konfusi menunjukkan bahwa overall accuracy hasil klasifikasi 
kelas penggunaan lahan hanya sebesar $60 \%$, sehingga kemungkinan terdapat kesalahan klasifikasi. Kesalahan klasifikasi penggunaan lahan dalam skala besar menyebabkan kesalahan estimasi luas per kelas.

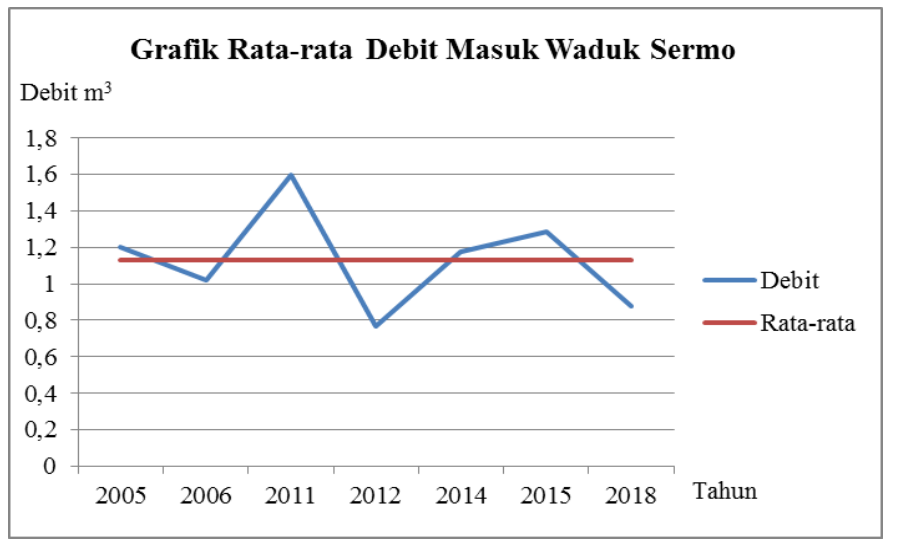

Gambar 3.12 Grafik rata-rata debit masuk Waduk Sermo

Estimasi luas kelas penggunaan lahan yang salah dapat mempengaruhi hasil akhir secara signifikan, sebab nilai sedimen rata-rata per hektar sebesar 6.152,853 ton.Volume sedimen dipengaruhi oleh debit air yang masuk ke waduk. Semakin tinggi debit yang masuk ke waduk akan semakin besar volume sedimen yang dihasilkan. Pada tahun 2018, volume sedimen yang kecil disebabkan oleh debit yang kecil pula. Dapat dilihat pada Gambar 3.10, bahwa rata-rata debit tahun 2018 di bawah rata-rata debit dari tahun 2005 sampai tahun 2018.

\section{Kesimpulan}

Dari kegiatan mengestimasi volume sedimentasi Waduk Sermo tahun 2018 menggunakan metode RUSLE, batimetri dan angkutan sedimen, dapat disimpulkan bahwa:

1. Hasil estimasi volume sedimentasi Waduk Sermo menggunakan metode RUSLE, batimetri dan angkutan sedimen menghasilkan volume dan laju ketebalan berturut-turut sebesar 184.158,5796 $\mathrm{m}^{3} /$ tahun, $163.151,1726 \mathrm{~m}^{3} /$ tahun dan 149.959,8001 $\mathrm{m}^{3} /$ tahun serta $8,687 \mathrm{~mm} /$ tahun, $7,790 \mathrm{~mm} /$ tahun dan 7,074 mm/tahun

2. Dibandingkan dengan metode RUSLE dan angkutan sedimen, metode batimetri cenderung lebih baik sebagai referensi estimasi volume sedimentasi Waduk Sermo. Sebab persentase selisih metode angkutan sedimen paling kecil yaitu $-0,766 \%$. Namun demikian, nilai RSD metode RUSLE, batimetri dan angkutan sedimen sebesar 10,658 \% sehingga diklasifikasikan ke dalam tingkatan ketelitian rendah.

\section{Referensi}

Ashari, A., 2013. "Kajian Tingkat Erodibilitas Beberapa Jenis Tanah di Pegunungan Baturagung Desa Putat dan Nglanggeran Kecamatan Patuk Kabupaten Gunungkidul”, Informasi, Vol. XXXIX (1), hal. 1531.

Fauzi, R.M.Z., dan Maryono., 2016. "Kajian Erosi dan Hasil Sedimen Untuk Konservasi Lahan DAS Kreo Hulu", Jurnal Pembangunan Wilayah \& Kota, Vol. 12 (4), hal. 429-445.

Haas, M., 2001, Project Performance Audit Report on the Integrated Irrigation Sector Project in Indonesia, Asian Development Bank, International Organization.

Hadiharyanto, S., 2003, Kajian Metode RUSLE untuk Menaksir Laju Erosi DAS Embung Banyukuwung di Kabupaten Rembang, Tesis, Fakultas Teknik, Universitas Diponegoro, Semarang.

Hakim, L., 2017, Penentuan Kecepatan Sedimentasi Waduk Sermo dengan Pendekatan USLE dan Pengukuran Kandungan Tanah dalam Air yang Masuk ke dalam Waduk, Skripsi, Fakultas Teknik, Universitas Gadjah Mada, Yogyakarta.

Kementerian Kehutanan., 2009, Peraturan Menteri No 32 Tahun 2009 tentang Tata Cara Penyusunan Rencana Teknik Rehabilitasi Hutan dan Lahan Daerah Aliran Sungai, Kementerian Kehutanan, Jakarta.

Kironoto., 2003, Transpor Sedimen, PPS-Teknik Sipil, Universitas Gadjah Mada, Yogyakarta.

Prasannakumar, V., et al, 2012. Estimation of Soil Erosion Risk within a Small Mountainous Sub-watershed in Kerala India using Revised Universal Soil Loss Equation (RUSLE) and Geo-information Technology. Geoscience Frontiers, Elsevier B.V., Vol. 3 (2), hal. 209-215.

Rassarandi, F. D., Santosa, P. B., \& Harintaka. (2018). Pemetaan Tingkat Bahaya Erosi Menggunakan Metode RUSLE (Revised Universal Soil Loss Equation) dan SIG di Sub DAS Kali Progo Hulu. Prosiding Simposium Infrastruktur Informasi Geospasial. http://doi.org/10.1109/SIIG2018.001

Sumardi., 2010, Tinjauan Umum Validasi Metode Analisis, Pusat Penelitian Kimia LIPI, Bandung.

Supangat, dkk., 2014, Teknik Pengukuran Hasil Sedimen, Balai Penelitian Teknologi Kehutanan Pengelolaan Daerah Aliran Sungai, Surakarta.

Wicaksono, I.2014.Prediksi Kecepatan Sedimentasi Waduk Sermo Berdasarkan Data Pengukuran Batimetri Multi Temporal, Skripsi, Fakultas Teknik, Universitas Gadjah Mada, Yogyakarta.

\section{Pernyataan Konflik Kepentingan}

Penulis menyatakan tidak ada konflik kepentingan dalam artikel ini (The authors declare no competing interest). 